\title{
A comparison of the quantitative anatomy of the bronchi in normal subjects, in status asthmaticus, in chronic bronchitis, and in emphysema
}

\author{
M. S. DUN I L L, G.R. MASSARELLA, A N J . A. A N DER SON \\ From the Department of Pathology, Radcliffe Infirmary, and the Department of Biomathematics, Oxford
}

\begin{abstract}
The quantitative anatomy of the bronchi has been studied in sudden deaths in normal subjects, in deaths from status asthmaticus and chronic bronchitis, and in patients with emphysema. In the normal bronchi the observed range of values for the percentage volume of mucous glands was between 7.6 and 16.7 . In the status asthmaticus group the mucous gland volume was greatly increased and in no case was there an overlap with the normal subjects. In the 19 cases of chronic bronchitis, two cases had values of 15.2 and $15.4 \%$ respectively, but all the others had values higher than the normal range and, in two instances, values of over $40 \%$ were obtained. The values obtained for mucous gland volume in the bronchi in emphysema were variable, approximately half being within the normal range. The bronchial smooth muscle accounted for $4 \cdot 6+2 \cdot 2 \%$ of the volume of the normal bronchial wall. The values obtained in chronic bronchitis and emphysema did not differ significantly from this but in those dying of status asthmaticus there was a very significant increase with a mean value of $11 \cdot 9 \pm 3 \cdot 36$.
\end{abstract}

In a previous paper (Dunnill, 1960) the pathological anatomy of the bronchi in asthma was described with special reference to the mucosal changes. The outstanding feature at necropsy was the presence of numerous plugs of mucus in the airways. Histologically, shedding of the ciliated bronchial mucosa cells was prominent, and this was attributed to a transudation of oedema fluid from the submucosa. The loss of the ciliated epithelium, together with interference with the action of the remaining ciliated cells by the oedema fluid, were considered to be the essential factors in the failure of clearance of the bronchial secretions in asthma. The finding of smooth muscle hypertrophy emphasized by Huber and Koessler (1922) was also noted. The present paper is concerned with the quantitative differences in the bronchial wall between normal subjects and those with status asthmaticus, chronic bronchitis, and emphysema.

\section{MATERIALS AND METHODS}

The bronchi were divided into four groups, and were from (1) normal individuals who had died suddenly, usually a traumatic death, with no previous history of chronic bronchitis; (2) patients who had died in status asthmaticus; (3) patients who had died with a history of chronic airways obstruction with expectoration and who, on pathological examination of their inflated lungs, were found not to have any destructive emphysema-chronic bronchities; (4) patients who had died with chronic airways obstruction and were found at necropsy to have one of the varieties of destructive emphysema.

The majority of the lungs were fixed by the formalin steam method of Weibel and Vidone (i961), but ino the status asthmaticus lungs, due to the dense bron chial exudate, this was often not possible, and the lungs were fixed by perfusion of the vessels with $10 \%$ formol saline.

Transverse histological sections, $5 \mu$ thick, were $\stackrel{\circ}{3}$ taken at three different levels from each bronchus $D$ selected (vide infra). Points of bifurcation were avoided. The sections were stained by the Masson N trichrome and periodic acid Schiff techniques, as well ${ }^{\mathrm{N}}$ as by haematoxylin and eosin. Sections. viewed with $\tilde{O}$ a Leitz Ortholux microscope fitted with a $\times 4$ objec-N tive and a projection mirror, were projected on to a piece of Bristol board with a point-counting grid drawn on it, the points being placed at the anglese of equilateral triangles of side $0.6 \mathrm{~cm}$. The details and $\Phi$ rationale of the point-counting procedure have been? described in previous papers (Dunnill, 1962; Ander- 7 son and Dunnill, 1964). Points falling on the bronchial wall were allocated to cartilage, muscle, mucous $\stackrel{\mathbb{Q}}{\mathcal{Q}}$ gland or 'connective tissue'. The latter category in- $\mathbb{\mathbb { D }}$ cluded any structures not embraced by the other terms. 
In all cases segmental bronchi were used. The main bronchi were not measured because of the excessive quantity of cartilage present. It was important to compare bronchi of the same size. At first sight it might seem logical to use bronchi of the same internal diameter, but this method was rejected because disease processes may affect this measurement by fibrosis or oedema. Bronchi with a similar absolute number of points falling on cartilage, i.e., with a similar absolute cross-sectional area of cartilage, were used, as it was considered that the bronchial cartilage was a reasonably constant feature of the bronchi; although it may, in long-standing chronic bronchitis, undergo calcification or ossification, it does not suffer any significant size change. Thus bronchi with between 100 and 200 points falling on cartilage were compared. The absolute number of points, rather than the percentage of points falling on cartilage, was taken, since the latter may alter with oedema of the bronchial wall or mucous gland hyperplasia.

\section{RESULTS}

The values obtained for each of the components in each case are shown in Figures 1, 2, and 3. The mean values, together with variance and standard deviation, are given in Table $I$.

T A B L E I

MEAN VALUES FOR COMPONENTS IN BRONCHIAL WALL IN THE FOUR GROUPS OF CASES

\begin{tabular}{|c|c|c|c|c|}
\hline & Normal & $\begin{array}{c}\text { Status } \\
\text { Asthmaticus }\end{array}$ & $\begin{array}{l}\text { Chronic } \\
\text { Bronchitis }\end{array}$ & Emphysema \\
\hline $\begin{array}{r}\text { Mucous } \\
\text { glands } \\
\text { Mean \% } \\
\text { Variance } \\
\text { S.D. .. }\end{array}$ & $\begin{array}{c}12 \cdot 7 \\
7 \cdot 5 \\
2 \cdot 74\end{array}$ & $\begin{array}{l}23 \cdot 4 \\
28 \cdot 7 \\
5 \cdot 36\end{array}$ & $\begin{array}{c}27 \cdot 8 \\
75 \cdot 1 \\
8 \cdot 67\end{array}$ & $\begin{array}{c}19 \cdot 6 \\
37 \cdot 2 \\
6 \cdot 10\end{array}$ \\
\hline $\begin{array}{l}\text { Muscle } \\
\text { Mean \% } \\
\text { Variance } \\
\text { s.D. .. }\end{array}$ & $\begin{array}{l}4 \cdot 6 \\
5 \cdot 0 \\
2 \cdot 24\end{array}$ & $\begin{array}{c}11.9 \\
11.3 \\
3.36\end{array}$ & $\begin{array}{l}5.8 \\
8.4 \\
2.90\end{array}$ & $\begin{array}{l}5 \cdot 5 \\
4 \cdot 0 \\
2 \cdot 00\end{array}$ \\
\hline $\begin{array}{c}\text { Connective } \\
\text { tissue } \\
\text { Mean \% } \\
\text { Variance } \\
\text { s.D. } \quad .\end{array}$ & $\begin{array}{c}55 \cdot 8 \\
26 \cdot 8 \\
5 \cdot 18\end{array}$ & $\begin{array}{c}42 \cdot 6 \\
16 \cdot 1 \\
4 \cdot 01\end{array}$ & $\begin{array}{c}42 \cdot 5 \\
71 \cdot 2 \\
8 \cdot 44\end{array}$ & $\begin{array}{c}50.6 \\
96.5 \\
9.82\end{array}$ \\
\hline $\begin{array}{c}\text { Cartilage } \\
\text { Mean \% } \\
\text { Variance } \\
\text { s.D. .. }\end{array}$ & $\begin{array}{c}26 \cdot 9 \\
24 \cdot 9 \\
4 \cdot 99\end{array}$ & $\begin{array}{c}22 \cdot 1 \\
34 \cdot 0 \\
5 \cdot 83\end{array}$ & $\begin{array}{c}23.9 \\
22 \cdot 0 \\
4.69\end{array}$ & $\begin{array}{c}24 \cdot 4 \\
89 \cdot 7 \\
9 \cdot 47\end{array}$ \\
\hline No. of lungs & 11 & 12 & 19 & 13 \\
\hline
\end{tabular}

In normal bronchi the observed range of values for the percentage of mucous glands is from $7 \cdot 6$ to $16 \cdot 7$. Figure 1 shows that the overlap between these subjects and those with chronic bronchitis alone is very small, there being only two bronchitics in the normal range with values of 15.2 and $15.4 \%$ respectively. No overlap is present in the status asthmaticus cases, but a considerable overlap is present between the normal subjects

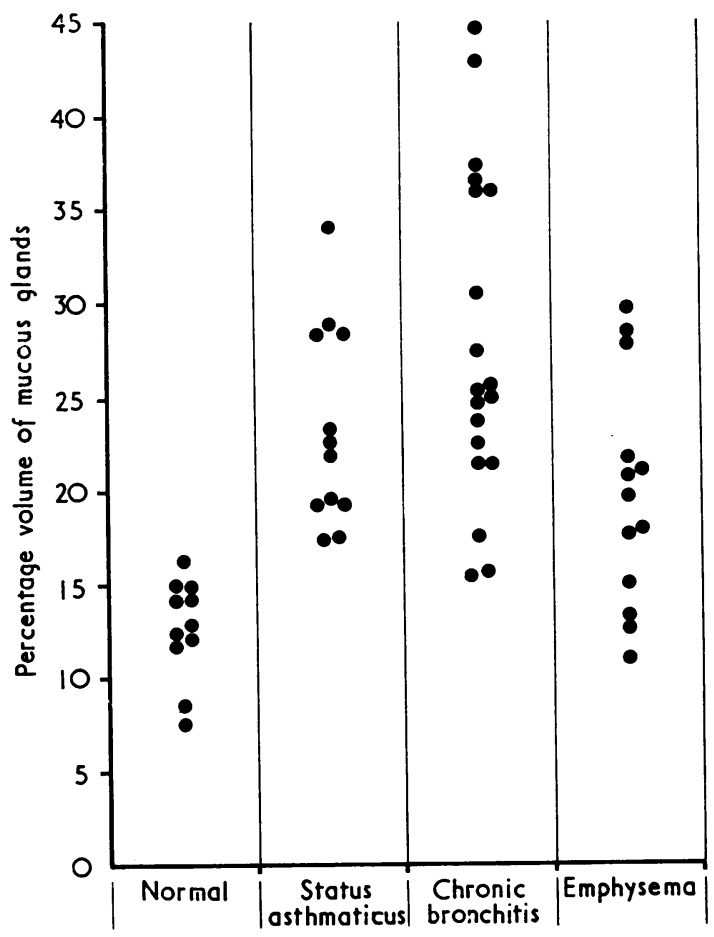

FIG. 1. The percentage volume of mucous glands in each case: in status asthmaticus and in chronic bronchitis there is clearly an increase as compared with the normal.

and those found at necropsy to be suffering from emphysema. Bartlett's test for differences between the variances of the four groups was significant at the $1 \%$ level, indicating that there was good evidence of differences between the variances of the four conditions. In this situation, an analysis of variance investigating the differences between the means of the four groups is not appropriate, so confidence intervals for the means of the groups are given in Table III. It follows that there is good reason to believe that the percentage of mucous glands is increased from the normal in status asthmaticus and chronic bronchitis.

The percentage of muscle in the bronchial wall in the various groups (Fig. 2) shows a striking difference between the status asthmaticus group and the rest. Bartlett's test for differences between the variances of the four groups was not significant at the $5 \%$ level so an analysis of variance was carried out (Table II). It showed that differences between the mean values of the four groups was significant at the $0.1 \%$ level. When the between groups sum of squares was partitioned into a component testing differences between the status 


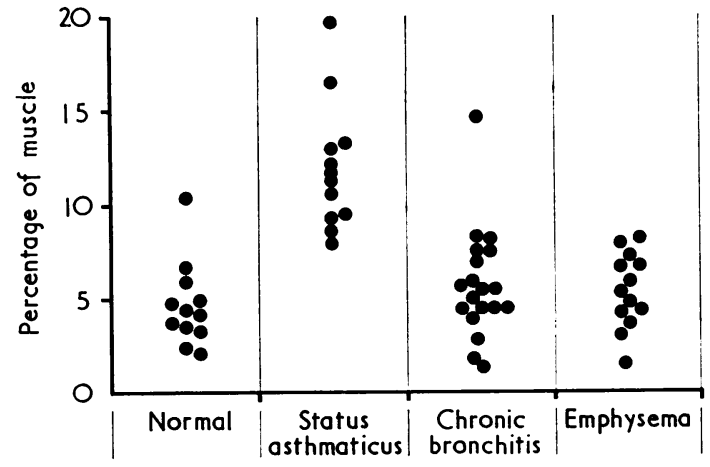

FIG. 2. The percentage of muscle estimated in the bronchi in each case: there is a marked increase in those with status asthmaticus.

T A B L E I I

ANALYSIS OF VARIANCE OF DIFFERENCES IN PERCENTAGE MUSCLE BETWEEN THE FOUR CLINICAL GROUPS

\begin{tabular}{|c|c|c|c|c|}
\hline Source & $\begin{array}{l}\text { Degrees of } \\
\text { Freedom }\end{array}$ & $\begin{array}{c}\text { Sum of } \\
\text { Squares }\end{array}$ & $\begin{array}{c}\text { Mean } \\
\text { Square }\end{array}$ & $\begin{array}{c}\text { Variance } \\
\text { Ratio }\end{array}$ \\
\hline $\begin{array}{l}\text { Between groups } \\
\text { Status asthmaticus }\end{array}$ & & $\begin{array}{l}418 \cdot 57 \\
404 \cdot 00\end{array}$ & $\begin{array}{l}139 \cdot 52 \\
404.00\end{array}$ & $\begin{array}{l}19 \cdot 1 \\
55 \cdot 3\end{array}$ \\
\hline $\left.\begin{array}{l}\quad \times \text { rest } \\
\text { Remainder } \\
\text { Residual }\end{array}\right\}$ & $\underset{51}{2}\}$ & $\left.\begin{array}{r}14.57 \\
372.21\end{array}\right\}$ & $\left.\begin{array}{l}7 \cdot 30 \\
7 \cdot 30\end{array}\right\}$ & 1.0 \\
\hline Total & 54 & $790 \cdot 78$ & & \\
\hline
\end{tabular}

asthmaticus group and the rest and a component for the remainder, it was found that the between group differences were wholly accounted for by differences between status asthmaticus and the rest. In only one case of chronic bronchitis was the percentage of muscle greatly increased, to a value of $14.7 \%$, and no explanation can be offered for this; the subject did not have the clinical features of asthma, and histologically the other features of asthma, such as pronounced basement membrane thickening and eosinophil infiltration, were not present.

Figure 3 shows the values for the connective tissue with considerable overlap between the groups. Bartlett's test for differences between the variances was significant at the $5 \%$ level, so again confidence intervals for the means are given in Table III. The reason for the wide spread of values found for this component is due to the variable degree of replacement by the other components, muscle and mucous glands, and also to the variable amount of submucosal oedema. The labelled component was itself made up of numerous elements, among which the most prominent were collagen, blood vessels, and cellular infiltrate. In the status asthmaticus deaths the cellular infiltrate contained numerous eosinophils,

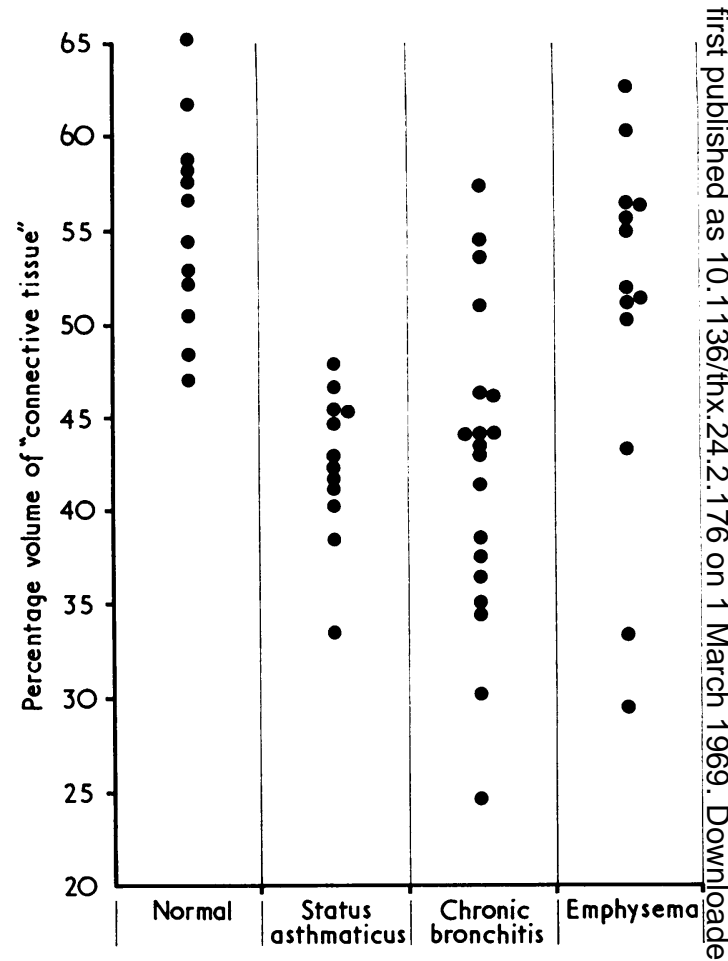

FIG. 3. The values obtained for the percentage of connec tive tissue: this component consisted of everything no믈 included under the headings cartilage, mucous glands or muscle.

T A B L E I I I

CONFIDENCE INTERVALS FOR MUCOUS GLAND AND CONNECTIVE TISSUE COMPONENTS IN THE FOUR GROUPST OF CASES

\begin{tabular}{|c|c|c|c|c|}
\hline $\begin{array}{c}95 \% \text { Confidence } \\
\text { Interval for Mean } \\
\% \text { of Tissue }\end{array}$ & Normal & $\begin{array}{l}\text { Status } \\
\text { Asthma- } \\
\text { ticus }\end{array}$ & $\begin{array}{l}\text { Chronic } \\
\text { Bronchitis }\end{array}$ & $\begin{array}{c}\text { Emphy- } \\
\text { sema }\end{array}$ \\
\hline $\begin{array}{l}\text { Mucous glands } \\
\text { Connective tissue }\end{array}$ & $\begin{array}{l}10 \cdot 9-14 \cdot 5 \\
52 \cdot 3-59 \cdot 3\end{array}$ & $\begin{array}{l}20 \cdot 0-26 \cdot 8 \\
40 \cdot 0-45 \cdot 1\end{array}$ & $\begin{array}{l}23 \cdot 6-32 \cdot 0 \\
38 \cdot 4-46 \cdot 6\end{array}$ & $\begin{array}{l}15 \cdot 9-23 \cdot 2 \\
44 \cdot 7-56 \cdot 5\end{array}$ \\
\hline
\end{tabular}

but it is worth noting that there was a large pro을 portion of lymphocytes as well. In the chronic bronchitics the cellular infiltrate consisted mainly of lymphocytes, and neutrophils were very scanty 0

The proportion of cartilage was by definition and design kept within strict absolute limits. It was generally of uniform appearance and in only one instance was partial ossification found, anc that in a case of emphysema without bronshia mucous gland hyperplasia.

\section{DISCUSSION}

In 1960 Reid defined chronic bronchitis in quanti $\frac{\Omega}{\mathbb{D}}$ tative terms by measuring the ratio, known as the Reid index, of the thickness of the mucous glands 
where they lay between the bronchial cartilage and the basement membrane of the mucosa to the total thickness of the wall from the perichondrium to the basement membrane. In making measurements on the bronchial wall in the present investigation the method of point counting was used (Dunnill, 1962; Anderson and Dunnill, 1964), as this has the advantage of (1) assessing all structures in the bronchial wall, including mucous glands which are present at points where there is no cartilage, and (2) being independent of the shape of the structures measured. The Reid index was not used because $(a)$ it will be influenced by crenation of the bronchial mucosa which is often present, $(b)$ there are only a few places where the mucosa and cartilage are parallel, and $(c)$ it does not take into account mucous glands which are situated behind or at the side of cartilage.

In the cases of clinical chronic bronchitis there is a distinct difference in the volume of the mucous glands as compared with normal subjects. Thurlbeck and Angus (1964) studied a randomly selected necropsy series and showed that the distribution curve for the Reid index was bell-shaped, indicating that no definite dividing line existed between bronchitics and non-bronchitics. The situation may well be analogous to that in hypertension (Pickering, 1961) and osteoporosis (Dunnill, Anderson, and Whitehead, 1967). The present findings in no way contradict this view, as the bronchitics were all advanced clinical cases and the number of normals was far too small for a meaningful distribution curve to be constructed.

The results also illustrate the distinct quantitative difference between the bronchi in deaths from status asthmaticus and from chronic bronchitis. In both there is mucous gland enlargement, but in status asthmaticus there is a very significant increase in the volume of smooth muscle, in some cases accounting for as much as $20 \%$ of the bronchial wall. The functional significance of this smooth muscle is in some doubt. In the trachea and main bronchi the muscle lies mainly posteriorly where the cartilages are deficient. In the smaller bronchi it occupies a position between the mucous membrane and the cartilage, and is a spiral structure likened by Ham (1957) to two bootlaces wound round a stick, one in a clockwise and the other in an anticlockwise direction. Miller (1947) defined the muscle as a geodesic network $\because$. . the ideal arrangement to withstand or produce pressures within the space enclosed by the surface, without tendency to slip along the surface'. There is a much greater proportion of smooth muscle in the walls of the smaller bronchi and bronchioles than in the larger airways. Grancher (1890) and Miller both found that in airways of $0.1 \mathrm{~cm}$. diameter there was at least five times as much muscle as in airways of $1.0 \mathrm{~cm}$. diameter. These workers considered that the function of the muscle was to prevent over-distension of the air passages during inspiration. In deaths from status asthmaticus the outstanding pathological features are the presence of a dense seromucinous exudate in the bronchial lumen and the loss of the ciliated bronchial mucosa, the latter feature resulting in a failure to clear the exudate (Dunnill, 1960). The cough reflex does not operate in the smaller bronchi, and it may be that the increased volume of smooth muscle is concerned with the clearance of the exudate, possibly by peristaltic action, as suggested in the cine-radiographic study of Holden and Ardran (1957).

Thurlbeck and Angus (1964) investigated the association between chronic bronchitis and emphysema in 106 necropsy cases and showed that the Reid index increased as the destructive emphysema became more extensive. The number of cases investigated here is too small for this relationship to be studied, but the data do show that bronchitis and emphysema can exist independently of one another. In many of these cases the emphysema was of a mixed variety, i.e., both panacinar and centrilobular types were present. The relationship between the quantity, type, and distribution of emphysema and the quantity of mucous glandular tissue in the bronchi is being further investigated.

One of us (M. S. D.) is in receipt of a personal grant from the Medical Research Council.

\section{REFERENCES}

Anderson, J. A., and Dunnill, M. S. (1964). Observations on the estimation of the quantity of emphysema in the lungs by the point-sampling method. Thorax, 20, 462.

Dunnill, M. S. (1960). The pathology of asthma, with special reference to changes in the bronchial mucosa. J. clin. Path., 13, 27.

(1962). Quantitative methods in the study of pulmonary pathology. Thorax, 17, 320.

- Anderson, J. A., and Whitehead, R. (1967). Quantitative histological studies on age changes in bone. J. Path. Bact., 94, 275.

Grancher, J. (1890). Maladies de l'Appareil Respiratoire, Tuberculose et Auscultation, p. 15. Doin, Paris.

Ham, A. W. (1957). Histology. 3rd ed., p. 636 et seq. Lippincott, Philadelphia.

Holden, W. S., and Ardran, G. M. (1957). Observations on the movements of the trachea and main bronchi in man. J. Fac. Radiol. (Lond.), 8, 267

Huber, H. L., and Koessler, K. K. (1922). The pathology of bronchial asthma. Arch. intern. Med., 30, 689.

Miller, W. S. (1947). The Lung, 2nd ed., p. 28. Thomas, Springfield, Illinois.

Pickering, G. (1961). The Nature of Essential Hypertension, pp. 9-21. Churchill, London.

Reid, Lynne. (1960). Measurement of the bronchial mucous gland layer: a diagnostic yardstick in chronic bronchitis. Thorax, 15,

Thurlbeck, W. M., and Angus, G. E. (1964). A distribution curve for chronic bronchitis. Ibid., 19, 436.

Weibel, E. R. and Vidone, R. A. (1961). Amer. Rev. resp. Dis., 84, 856. 